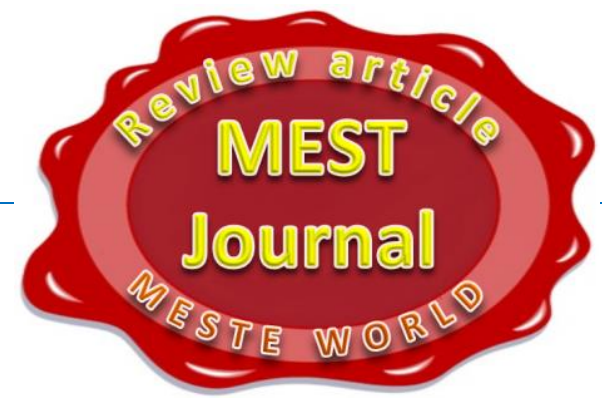

\title{
THE DEVELOPMENT OF THE LOGISTICS SYSTEM OF THE REPUBLIC OF BELARUS
}

\begin{abstract}
Anatoli Molokovitch
The Institute of Business and Management Technologies of the Belarusian State University, Minsk, Belarus
\end{abstract}

\section{(c) MESTE NGO}

JEL category: O, 03, 052, R4, R41

\begin{abstract}
:
In the article some questions of the development of logistics sector in the Republic of Belarus are considered. The favorable geographical position of Belarus determined a rapid development of logistics services in the country. Belarus is interested in growth of transit potential, the increase of accessibility of the remote areas, as well as the major European exporters. The most relevant evidence of this interest is an international project "Amber Coast Logistics", which is implemented in the framework of "Baltic Sea Region program" (funded by EU) and aims at increasing the volume of foreign trade in the region. Since the Index of Transit has been developed, the growth of cargo flows was forecasted as a result of the elimination of barriers for development of foreign economic activities in Belarus. The new transport corridors, linking the southern Baltic Sea region with the countries of the Customs Union and Ukraine have been proposed, as well as the new multi-modal transport chains through these corridors, oriented, first of all, to Belarus.
\end{abstract}

Keywords: logistics, traffic flows, index of transit, foreign trade, transport accessibility

\section{INTRODUCTION}

The modern stage of development of the world economy has been characterized by sharp competitive struggle for the spheres of influence on the basic commodity markets. Globalization of the economy causes a rapid growth of trade flows in the Euro-Asian continent. Growing economies of China, Japan, as well as the developed economics of European countries, are consuming more and more of the raw material

The address of the author:

Anatoli Molokovitch

拝三” Molokovitch@tut.by resources. At the same time, they produce modern high-tech engineering products, which have huge needs of the developing economy of the same China, Russia, Kazakhstan, Belarus, the Ukraine and other Post-Soviet republics.

In recent years, cargo flows in the direction of Europe - Russia - Ukraine - Kazakhstan China are quite stable. Nevertheless these flows have been already formed. The practice shows the rapid growth of foreign trade between these countries, and hence the growth of trade flows.

The dynamic development of the integration processes in the frames of the Customs Union of Belarus, Russia and Kazakhstan, has expanded 
the possibilities of our country for the development of logistics and transit of goods in the Europe-Asia direction.

Location of the Republic of Belarus in the heart of the European continent allows to become a specific bridge between the countries of Europe and Asia and to ensure the smooth movement of traffic flows on the main transport corridors passing through Belarus. This is well understood by the Republic's Government and conditions for the transit of cargoes through its territory are constantly improving. Bodies of State Management are constantly and systematically working to increase the transit of freight traffic through Belarus, contributing to the growth of trade turnover of the countries of the European Union with Asian States.

The cooperation in the sphere of logistics of railway transport with the neighboring States is rapidly developing. The most bright examples are: the international combined train "Viking“, which follows the route "Klaipeda-Minsk-Kiev"; specialized container train "Mongolian vector" on the route "Brest - Naushki - Ulan-Bator"; container train "Zubr" - on the route "Tallinn Riga - Minsk - Kiev"; container train "Mercury" on the route "Klaipeda /Kaliningrad - Minsk Moscow". The train "Viking" is sent to weekly, "Mongolian vector" - three times a month, "Zubr" and "Mercury" are in process of formation of the composition. The advantages of container trains are obvious. For example, the distance from the Port of Hamburg up to ports of China is about 21 $000 \mathrm{~km}$ and the term of cargoes delivery varies up to 30-40 days, while switching the flow of cargo in the direction of the railway transport reduces the time of delivery in 3 times.

\section{THE LEVEL OF DEVELOPMENT OF LOGISTICS IN BELARUS}

Activities that were conducted in the Republic of Belarus for the development of logistics, assessed as part of the Logistics Performance Index of the World Bank at the level of $91^{\text {st }}$ position in 2011, while in the previous year it was $74^{\text {th }}$ position. Considering the individual factors of Logistics Performance Index, it should be noted, that for the organization of international transport, Belarus is located at $107^{\text {th }}$ position in the World, on the timeliness of the goods delivery - at $114^{\text {th }}$ position, on the system of tracking the movement of goods - on the $98^{\text {th }}$ position, and on the efficiency of customs and border control - at $121^{\text {st }}$ position. In the LPI ranking for the year 2012, Republic of Belarus took the $91^{\text {st }}$ place from 155.
(Arvis, Mustra, Ojala, Shepherd, \& Saslavsky, 2012)

According to "The Efficiency of Customs and Border Control Indicator", Belarus has lost 43 percentage points, what is the worst indicator not only among the countries of the Commonwealth of Independent States (CIS), but also in the World (the worst dynamics has been observed only in some African and Asian countries: Syria, Libya, Eritrea etc.). This trend is conceptually impact on the overall picture of the Logistics Performance Index for the Republic of Belarus in 2011.

As can be seen, Customs is the bottleneck in determining index mentioned above. In general, the level of logistics development in Belarus is lower than in Latvia, Lithuania and Kazakhstan, but slightly higher than in Russia, which occupies $95^{\text {th }}$ position. In this connection, the Government of the country was given the task to implement a set of measures which would allow rising on 50$60^{\text {th }}$ places in this ranking. For this purpose, first of all, it is necessary to improve the legislation of the Republic of Belarus, reduce the number of formalities in the internal and border terminals, to simplify the conditions for obtaining of various permits and certificates.

As noted above, the most difficult place in the transport and logistics system of Belarus is the State Border. At the present time the State Border has only 34 road check points, which are equipped with devices of technical control, computerized and connected to the information lines, which allows to use new forms and methods of customs control and customs clearance of goods, based on the modern electronic technologies. New technologies allow reducing time of customs clearance and control through the use of electronic exchange of information between customs and participants of foreign economic activity. From June 17, 2012 compulsory preliminary informing about the goods imported to the Customs territory of the Customs Union was introduced on the road transport. According to this decision, the authorized economic operators should provide information in respect of imported road transport of goods of not less than two hours prior to their importation into the customs territory of the Customs Union.

Customs bodies of the States-members of the Customs Union, on whose territory the place of arrival of goods and transport vehicles is located, are obliged to carry out its analysis with the use of a risk management system within 2 hours from 
the moment of receipt of preliminary information. Further, the customs authorities carry out a comparison of the data contained in the transport and commercial documents, submitted by the carrier, with the information contained in the preliminary information. In the case of presentation of the preliminary information in the required volume, provided preliminary information is used as electronic copies of the transit declaration in the absence of differences preliminary information and data contained in the documents used as a transit declaration. The decision on further delivery of the goods is made no later than after 2 hours from the moment of registration of the transit declaration if there is no risk of noncompliance with the norms of legislation of the Customs Union.

The principle of preliminary information should also be applied for the rail cargo transport. However, this procedure is still not obligatory.

In the National transport regulatory and legal basis of the principle of freedom of transit - there is the list of documents, which should be provided at the border by the carrier. In addition, there are 4 criteria, on the basis of the unreliability of which customs authorities shall have the right to detain the goods: the name of the product, its quantity, gross weight and number of packages.

An important direction of development of transport-logistics activity in Belarus is the introduction of amendments and additions into the Code of the Republic of Belarus "On the ground" in the part of the transition of the property right to the ground when investing in the construction of a transport-logistics centers, in the Investment Code in the part of the extension of the rights of the concession and to the Tax Code in the part of exemption from fees for storage of goods under customs supervision and exemption from payment of the profit tax for a certain time.

Positive role to enhance the transit attractiveness played abolition of transport and other agreed types of controls at internal inter-state borders of the countries-participants of the Customs Union, which increased the speed of movement of transit vehicles. (EurAsEC, Koncepcija formirovanija Edinogo transportnogo prostranstva Evrazijskogo èkonomicheskogo soobshestva, 2008)

The concept of formation of single transport space, adopted in EurAsEC, provides the creation of transport-logistical chains and logistics terminals in the territory from Alma-Aty to Brest (EurAsEC, Concept of Establishment of the Common Transport Space of the Eurasian Economic Community, 2008). The strategy of creation and development of logistics centers of the EurAsEC is based on the provisions of the Agreement between EurAsEC Member States on establishing the Transport Union and the Concept of the formation of a Common Transport Space of the EurAsEC. This strategy covers the period up to the year 2020 and is designed to combine the practical efforts of the members of mentioned community to the joint implementation of the tasks of the EurAsEC in the sphere of transportation activity (EurAsEC, Strategija sozdanija i razvitija sistemy meždunarodnyh logističeskih centrov Evrazijskogo èkonomičeskogo soobŝestva (na period s 2009 po 2020 gody), 2008):

At the external borders of Belarus and Russia the uniform control of vehicles on the principle of "one-stop" is carried out from 2011. As a result of this measure, the number of transit trips of freight cars owned by foreign carriers in 2011, has increased compared to 2010 more than in 21 percent.

Further enhancing the attractiveness of the automobile transit through the territory of the Republic of Belarus has contributed to the transfer of the 2011 monitoring of implementation of international road transport with the KazakhRussian border to the external border of the Customs Union.

Particular attention in the implementation of the policy aimed at increasing the transit potential is paid to development of the international transport corridors infrastructure. The length of motor roads with a carrying capacity of 11.5 tons per axle which are included in the international transport corridors has increased by 327 kilometers over the past three years. The maximum speed of movement on the $2^{\text {nd }}$ transport corridor through the territory of Belarus for freight transport is $100 \mathrm{~km} / \mathrm{h}$, while in Russia only $70 \mathrm{~km} / \mathrm{h}$.

\section{THE INTERNATIONAL COOPERATION ON THE DEVELOPMENT OF LOGISTICS IN BELARUS}

Belarus is interested in the growth of transit potential and increasing the accessibility of remote areas, as well as the major European exporters. This fact was confirmed by the approval of an international project „Amber Coast Logistics", which is realized in the framework of 
the „Baltic Sea Region program” (European Commission). Implementation period of this project is $2010-2014$ years (ACL, 2012).

There are 6 countries involved in the project: Germany, Denmark, Poland, Lithuania, Latvia and Belarus. Project partnership is represented by 20 partner organizations, including 4 partners from Belarus.

School of Business and Management Technologies of the Belarusian State University is one of the performers and at the same time acts as a National coordinator of the project in Belarus.

The project aims to expand the volume of trade between the countries of the Baltic Sea region and Belarus, Russia, Kazakhstan and the Ukraine. This should be achieved through the following activities:

- increasing the accessibility of the remote areas of these countries,

- the application of multimodal cargo transportation systems,

- formation of new transport corridors,

- informing the carriers about the peculiarities of transport policies in partner countries,

- simplification of customs procedures of border crossing.

\subsection{Study of legal acts in the sphere of} international cargo transportation

A study of normative-legal acts in the sphere of international cargo transportation was conducted in the framework of the project "Amber Coast Logistics". The customs laws and regulations which are in force in the European Union and Belarus were also included in this analysis.

In particular, there were considered the following documents: the international legal instruments concluded between the Commonwealth of Independent States (CIS) Member States, the legislative acts of the Republic of Belarus in the sphere of international cargo transportation, customs rules, agreements on trade in goods between the EU and Belarus. This research has shown that in general the legislative acts of the Republic of Belarus have been harmonized with the corresponding acts of the European Union.

Nevertheless, there are certain problems, such as:

- the absence of a single customs control with use of inspection complexes at the customs office of departure;
- the lack of joint customs control by the customs authorities of Lithuania at all crossing points on the principle of "One stop";

- the absence of a joint inspection of the goods ADR before the beginning of transportation of the Customs Service and Ministry of Emergency Situations;

- highly regulated customs procedure on withdrawal of marriage and import new equipment under the terms of the old transaction;

- low throughput speed of data transmission in electronic preliminary information of the customs bodies for the import/export of goods in/from/through the Republic of Belarus (the speed is less than $15 \mathrm{Kbit} / \mathrm{sec}$ );

- complicated procedure of declaring the customs value of the goods;

- instead of being a declaration of delivery of the goods necessary to use the shipping documents, for example, a road consignment note together with the international standard of the convention on the contract for the international carriage of goods by road (CMR) (UNECE, 1956);

- the need to reduce the time of customs control and clearance of goods in a logistics center up to 4 hours from the moment of the adoption of a full package of document, by applying the European technology of customs clearance "Trust relationship“;

- the lack of priority or accelerated procedure of customs clearance of the goods within the country and across the border;

- for the processing of goods at the border is not taken into account the positive image of the national and international carrier, as well as the image of the shipper/consignee;

- multiple overstatement of prices for the accommodation of the goods in the transport-logistics centers to 9-11 Euro per one pallet place instead of $\$ 2-2.5$ as in other countries;

- not legally establish the availability of information about prepared by the normative documents of foreign trade activities, procedures, customs, 
phytosanitary, quarantine and other types of processing and control;

- the lack of services provided by organizations on certification sanitary control and certification in the internal customs posts, for which it is necessary to apply to the Central authority of these structures;

- the need for representation in various governmental authorities of the country of the documents, which do not have access to them direct relationship: for example, to the authorities for the issuance of hygienic certificate, a copy of a foreign economic contract with a CMR consignment note and the mark of the customs on the placing of the goods in the customs control zone;

- excessive demands to the design of the originals of documents on protected from fakes paper on a model form, etc.;

- many of assuring the manufacturer, provider, carrier, forwarder, a notary, an issuing authority, etc. copies of documents;

- the need to provide documents, which are a by-cognitive nature of the information (documents of the receipt of the payment on the letter of credit, for the distribution of the costs of transport, documents on currency operations, confirmation of residence, simplification of customs clearance, etc.);

- restriction of the conditions of admissibility or conditional recognition of the documents sent by e-mail and Fax;

- extremely inflated administrative responsibility for the consequences of the submission of improper (wrong) documents in the field of foreign economic activity. A measure of responsibility - from large fines to the full confiscation of the goods or even a vehicle;

- a number of other less important issues.

Therefore, these discrepancies should be eliminated at nearest future.

\subsection{The development of the transit index}

In the framework of the project it is tasked for the first time to develop the index of transit on the basis of the basic criteria of the legislative acts. These criteria are grouped into five areas: customs clearance, technical specifications, network access and tariff policy, requirements for drivers of vehicles, special requirements.

The first group includes four criteria (customs clearance):

1. Pre-shipment inspection: in what period is it acts? On which countries has it been spread? How much does it cost? How widely has it been implemented? For what groups of the goods it has been applied and whether it is an obligatory procedure?

2. Customs fees: how has the amount of dues for customs clearance of goods varied?

3. The customs value: how has the procedure for determining the value when moving goods across the border varied?

4. Customs control: in what year has it been finally abolished on the border with the Russian Federation? To check, if this control is absent in any of the years of the studied period?

The second group includes four criteria (technical specifications):

1. Restrictions on the movement of vehicles: in what years restrictions on movement in the daytime were applied (in the spring and summer periods)?

2. The maximum permissible axle load: The General requirements for the maximum permissible load on the axle has changed; the maximum permissible axle load in the period of limitations? If there are any restrictions applied on all the roads?

3. Vehicle dimensions: Whether the General requirements for the size of the vehicles were changed?

4. Tachographs: If the rules of using tachographs have changed, and if they differ from European?

The third group includes four criteria (network access and tariff policy):

1. The fee for travel on public roads: how 
varied the value of this collection with foreign carriers?

2. Fares: how changing the value of a payment for travel on highway M1/E30?

3. Other charges: if any of the other charges against carriers for transportation on the territory of Belarus were applied?

4. Payment for transportation of heavy and oversized vehicles: how has the fee for automobile roads of General use changed?

The fourth group includes two criteria (requirements for drivers of vehicles):

1. Charges with the drivers of vehicles shall apply: is there payment of any fees (ecology, medical insurance, etc.) for the drivers of vehicles (except for the visa)?

2. The mode of work and rest of drivers: were the requirements of the regime of work and rest of the drivers changed?

The fifth group includes three criteria (special requirements):

1. The customs escort: what goods should obligatory be accompanied and how their value is changing?

2. Types of control: what significant changes have taken place in carrying out veterinary and phytosanitary control (requirements to the submitted documents, the complexity and cost of procedures)?

3. Prohibitions: if there any restrictive measures to the transit of certain types of goods, such as waste and dangerous goods?

The entire study was conducted by the 17 criteria for the period from 1995 to 2010 . According to the results of processing the initial data, a correlation model of dependence of the freight traffic volume in/from/through of the Republic of Belarus and these criteria will be built. On the basis of the developed model, the forecast of growth of cargo volumes up to the year 2020 was done. It is based on the realization of a complex of measures designed to eliminate the existing problems in the field of international cargo transportation, as well as deeper harmonization of legal acts of Belarus and the European Union.

\section{NEW MULTIMODAL TRANSPORT CHAINS}

On the basis of prepared forecast of volumes of cargo transportations, five of the most promising transport corridors between the Baltic Sea Region and the countries of the Customs Union and Ukraine were identified:

- This corridor A - Ventspils - Riga Moscow,

- corridor B with its two directions:

1 - Riga-Vilnius-Minsk-Kiev,

2 - Riga-Smolensk,

- corridor C - route under the Baltic sea between its southern ports,

- corridor D - Klaipeda-Vilnius-MinskMoscow,

- corridor E - Hamburg-Berlin-WarsawMinsk-Moscow.

Using data transport corridors developed multimodal transport chains, which allow reducing the environmental load due to the shift of freight from road to sea and railway.

Studies of existing transport chains have shown that the potential of the Republic of Belarus is used to a small extent. In general, all goods are carried in Moscow or in the Moscow region, where they undergo customs clearance, processed and then sent to the consignee back to Belarus, as well as Kazakhstan and the Ukraine. Such routes have been developed as a result of the enormous volumes of cargo flows following in Moscow, thanks to which the importers receive a big discount, eliminating additional transportation expenses due to increase of the length of the route. In this region a fairly well-developed logistics infrastructure with a wide variety of rendering logistics services has formed. However, the existing capacity of the logistics centers now is heavily overloaded, and their further development will lead to the growth of total logistics costs due to increasing the load on the whole infrastructure: roads, railways, passenger transport, energy, systems of life, etc. The consequences of such development are: a complicated ecological situation, the shortage of human and financial resources for the further development of logistics infrastructure.

Therefore it is necessary to change the existing transport chains, making full use of the geographical position of the Republic of Belarus. This should be a network of large logistics centers, which will provide the whole complex of logistics services of 3PL and 4PL operators.

Meanwhile, the logistics sector in Belarus is in the initial stage of development. The Program of development of the logistics system of Belarus till 
2015 was adopted only in 2008 as well as the Program of development of the transit potential of the Republic of Belarus for 2010-2015. Both programs determine the directions of logistics development in the Republic. In accordance with these Programs, 11 logistic centers with quite a wide range of logistics services are already functioning on the territory of Belarus. Not far from Minsk there is in the process of building the Europe's largest transport-and-logistics center called "Prilesye". This center will be located on an area of 83 hectares. The unique location provides direct access to the Minsk Ring Way, the European transport corridor №2 (Berlin-WarsawMinsk-Moscow), motorway M-4 (Minsk-Mogilev) and the National airport "Minsk-2". The main purpose of TLC can be divided into two areas: service of the Belarusian export and import on the borders of Minsk and Minsk region and service of transit cargo flows. (Sovet Ministrov ... 2010)

Delivery of all goods in the complex will be carried out as by motor roads and by rail to the complex from the territory of one of the largest industrial centers of Minsk. Warehouse premises with a total area of storage in 200 thousand square meters, are designed on the principle of universal modules and can satisfy the most demanding clients. There also an intermodal terminal with an area of $80,000 \mathrm{~m}^{2}$ will be made.

In $40 \mathrm{~km}$ from Minsk on the territory of 79 hectares, close to the National airport „Minsk-2“, has been started the construction of multimodal logistic center under the name Air Logistic Park. The center is located in 2 kilometers from the motorway M1, which is part of the Trans European corridor № 2. The distance to the capitals of neighboring States is: Vilnius - 172 km, Riga - 403 km, Warsaw - 477 km, Kiev - 437 $\mathrm{km}$, Moscow - $678 \mathrm{~km}$.

In the Air Logistics Park the following infrastructure and logistics services will be available:

- cargo air terminal with direct access to the parking of aircraft;

- railway terminal, storage and handling of containers;

- services of forwarding;

- warehouses of class A;

- business center;

- customs registration and clearance;

- filling station and the maintenance of automobiles;

- restaurant and hotel;
- guarded parking for trailers;

- car parking, playground for maneuvering;

- industrial zone.

In addition, about 40 logistics centers are in the stage of construction and by the end of 2015 it is expected that their number will reach 50 (Sovet Ministrov, 2008).

The development of the logistics activity in Belarus is particularly relevant especially in connection with the creation of the Customs Union and the Single Economic Space. In the new conditions it is economic expedient to make the delivery of goods from Western Europe to the logistics centers of our country, make their customs clearance, cargo handling and send them to the Customs Union countries on lower tariffs. Also effective the delivery of goods from the countries of the Customs Union to the logistics centers of Belarus, which will do their customs clearance of cargoes and sending them in the countries of Western Europe under the customs control. The new multimodal schemes of cargo transportation will be used here, ensuring lower overall costs and higher ecological compatibility of delivery.

The reorientation of the major traffic flows in direction West - East and North - South through Belarus will provide the development of the transport industry of the country and allow to create a modern infrastructure of roadside service along major transport corridors and maintain them at a modern European level.

It is expected that as a result of the implementation of these activities the total amount of incomes from transit in 2015 (without accounting of incomes from the transit of oil and the cost of services on transit of natural gas through trunk pipelines) will amount to $\$ 2.4$ billion, or $160.2 \%$ to the level of the year 2010 , and also - of 2.6-2.7\% in the GDP. The volume of revenues from the implementation of transit flights by foreign aircraft to $\$ 73.8$ million or $142.8 \%$ to the level of the year 2010 , the transit of goods and passengers by rail - \$691 million $(135 \%)$, the implementation of the residents of the international road transport through the territory of the country - \$392.2 million (160\%), services of the objects of roadside service is $\$ 1.2$ billion (180.3\%).

Deductions in the budget of the executed residents of international road transport in transit through the Republic of Belarus in 2015 will amount to $\$ 25.4$ million, or $155 \%$ to the level of the year 2010. Deductions in the budget for travel 
by automobile roads of general use in 2015 will reach $\$ 11.2$ million $(160 \%)$, and payment for travel by highway M-1/E30 - $\$ 79$ million (164.6\%).

\section{CONCLUSION}

The globalization of the economy caused a rapid growth of trade flows in the Euro-Asian direction, because of the increasing volumes of consumption of raw material resources, as well as the increasing needs of developing countries in the modern high-tech products.

The dynamic development of the world integration processes, as well as the creation of the Customs Union of Belarus, Russia and Kazakhstan, expanded the possibilities of the Republic of Belarus for the development of logistics and increase on this basis the transit of goods through its territory.

At the present time the logistics sector in Belarus is in the initial stage of development. The Program of development of the logistics system of Belarus till 2015 and the Program of development of the transit potential of the Republic of Belarus for 2010 - 2015 were adopted only in 2008. In accordance with these programs 11 logistics centers with a wide range of logistics services provided is already functioning on the territory of Belarus and it is planned to build about 40 .

The work which is conducted in the Republic on the development of the logistics, estimated by the World Bank at the level of 91 seats for the year 2011, while in 2010 it was 74th place. Analyzing the individual components of the index, it should be noted that the most vulnerable area is the customs and border control, to which Belarus is located at $121 \mathrm{st}$ place. This is the worst indicator of not only among Commonwealth of Independent States (CIS) countries, but also all over the world. This trend has affected the overall picture of the Logistics Performance Index for the Republic of Belarus for the year 2011.

In this regard legislative acts in the sphere of international cargo transportation and foreign trade activities, as well as customs legislation have been investigated. In the result there were revealed the key bottlenecks that hinder the development of foreign trade and transit through the territory of the Republic and the actions on their elimination have been proposed. The great importance in the development of logistics in Belarus is given to the international project "Amber Coast Logistics"(implementation period 2011 - 2014). The project aims to expand the volume of trade between the countries of the Baltic Sea region and Belarus, Russia, Kazakhstan and Ukraine due to increase of accessibility in remote areas of these countries, the application of multimodal cargo transportation systems, formation of new transport corridors, information carriers about the peculiarities of transport policies in partner countries, as well as the simplification of customs procedures of border crossing.

In the framework of the project it is tasked for the first time to develop the index of transit on the basis of the basic criteria of the legislative acts. These criteria are grouped into five areas: customs clearance, technical specifications, network access and tariff policy, requirements for drivers of vehicles, special requirements. All study covers 17 criteria for the period from 1995 to 2010. According to the results of processing the initial data is built correlation model of dependence of the volume of freight traffic in/from/through the Republic of Belarus and data criteria. On the basis of the developed model, the forecast of growth of cargo volumes up to the year 2020 was done. It is based on the realization of a complex of measures designed to eliminate the existing problems in the field of international cargo transportation, as well as deeper harmonization of legal acts of Belarus and the European Union. According to the forecast of volumes of cargo transportations, five of the most promising transport corridors between the Baltic Sea region and the countries of the Customs Union and Ukraine were identified. This corridor A - Ventspils-RigaMoscow, entrance $B$ has two directions: 1 Riga-Vilnius-Minsk-Kyiv, 2 - Riga-the city of Smolensk, a corridor C - route under the Baltic Sea between its southern ports, entrance D Klaipeda-Vilnius-Minsk-Moscow, corridor E Hamburg-Berlin-Warsaw-Minsk-Moscow. Using above mentioned transport corridors, multimodal transport chains have been developed. They allow reducing the load on the environment due to the shift of freight from road to sea and rail, making full use of the geographical position of the Republic of Belarus.

\section{Works Cited}

ACL. (2012, 04 11). Amber Coast Logistics - Connecting remote areas. Retrieved from Amber Coast Logistics: http://www.ambercoastlogistics.eu/node/2 
Arvis, J.-F., Mustra, M. A., Ojala, L., Shepherd, B., \& Saslavsky, D. (2012, 05 11). Connecting to compete 2012 - Trade logistics in the global economy. Retrieved 03 03, 2013, from The World Bank: 1336654966193/LPI_2012_final.pdf

http://siteresources.worldbank.org/TRADE/Resources/239070-

EurAsEC. (2008, 02 26). Concept of Establishment of the Common Transport Space of the Eurasian Economic Community. Retrieved from Evrazijskoe èkonomicheskoe soobshestvo: http://www.evrazes.com/docs/view/156

EurAsEC. (2008, 01 25). Koncepcija formirovanija Edinogo transportnogo prostranstva Evrazijskogo èkonomicheskogo soobshestva. Retrieved from Evrazijskoe èkonomicheskoe soobshestvo: http://www.evrazes.com/docs/view/68

EurAsEC. (2008, 12 02). Strategija sozdanija i razvitija sistemy meždunarodnyh logističeskih centrov Evrazijskogo èkonomičeskogo soobŝestva (na period s 2009 po 2020 gody). Retrieved from Evrazijskoe èkonomičeskoe soobŝestvo: http://www.evrazes.com/docs/view/434

Sovet Ministrov. (2008, 08 29). O Programme razvitija logisticheskoj sistemy Respubliki Belarus' na period do 2015 goda. Retrieved from Pravo.by: http://pravo.by/main.aspx?guid=3871\&p0=C20801249\&p2=\%7BNRPA\%7D

Sovet Ministrov. (2010, 08 09). Ob utverzhdenii strategii razvitija tranzitnogo potenciala Respubliki Belarus' na 2011-2015 gody. Retrieved from Pravo.by: http://pravo.by/main.aspx?guid=3871\&p0=C21001181\&p2=\%7BNRPA\%7D

UNECE. (1956, 05 19). Convention on the contract for the international carriage of goods by road (CMR). Retrieved from United Nation Economic Commision for Europe: http://www.unece.org/fileadmin/DAM/trans/conventn/cmr_e.pdf

Received for publication: $\quad 07.01 .2013$

Revision received: $\quad 28.02 .2013$

Accepted for publication: $\quad 14.03 .2013$

\section{How to cite this article?}

Style - APA Sixth Edition:

Molokovitch, A. (2013, 07 15). The development of the logistics system of the Republic of Belarus. (Z. Čekerevac, Ed.) MEST Journal, 1(2), 62-70. doi:10.12709/mest.01.01.02.05

Style - Chicago Fifteenth Edition:

Molokovitch, Anatoli. "The development of the logistics system of the Republic of Belarus." Edited by Zoran Čekerevac. MEST Journal (MESTE) 1, no. 2 (07 2013): 62-70.

Style - GOST Name Sort:

Molokovitch Anatoli The development of the logistics system of the Republic of Belarus [Journal] = The logistic system of the Belarus // MEST Journal / ed. Čekerevac Zoran. - Belgrade : MESTE, 07 15, 2013. - 2 : Vol. 1. - pp. 62-70. - ISSN 2334-7058 (Online); ISSN 2334-7171.

Style - Harvard Anglia:

Molokovitch, A., 2013. The development of the logistics system of the Republic of Belarus. MEST Journal, 15 07, 1(2), pp. 62-70.

Style - ISO 690 Numerical Reference:

The development of the logistics system of the Republic of Belarus. Molokovitch, Anatoli. [ed.] Zoran Čekerevac. 2, Belgrade : MESTE, 07 15, 2013, MEST Journal, Vol. 1, pp. 62-70. ISSN 2334-7058 (Online); ISSN 2334-7171. 